\title{
Federal Taxation: Pension Plan Vesting Differentials Not Per Se Discriminatory
}

In United States v. Hall the Court of Appeals for the Eighth Circuit refused to hold that employer contributions to a pension plan are per se discriminatory and nondeductible under section $40 \mathrm{l}$ (a)(4) of the Internal Revenue Code of $1954^{2}$ where the plan provides for immediate vesting for partners and for deferred vesting for other employees. Carefully circumscribing its holding, the court went on to state that such a pension plan would be discriminatory if its eligibility and vesting provisions operate to exclude from the practical benefits of the plan so many employees "that its value to the employee group as a whole is illusory." ${ }^{3}$ The Fargo Medical Clinic established a money-purchase plan ${ }^{4}$ for its thirty-three physician partners. In addition, the clinic provided the employees of the partnership with a unit-benefit pension plan. ${ }^{5}$ While the partners' plan provided for immediate vesting, an employee's benefits did not vest until he had completed fifteen years of service and attained age fifty. The Commissioner disallowed a partner's claim of a deduction in the amount of his contribution, reasoning that the two plans discriminated against the employees since under no circumstances would the partner lose his benefits while an employee's termination of employment before the time of vesting would result in total forfeiture of his benefits. Finding that the benefits under the employees' plan were actually more favorable than those provided by the partners' plan, the district court held for the taxpayer. ${ }^{6}$ The court of appeals reversed and remanded, instructing the trial court to hear further evidence on whether the practical effect of the different vesting provisions was to render the value of the plan illusory to the employee group as a whole.

1398 F.2d 383 (8th Cir. 1968).

${ }^{2}$ INT. Rev. CODE OF 1954, § 401 (a)(4).

398 F.2d at 390.

- A money-purchase plan normally provides for a stated employer contribution equal to a fixed percentage of each partner's annual compensation with benefits payable upon retirement consisting of the total contributions plus accumulated investment earnings. See Alexander, Advantages and Disadvantages of Pension. Profit-Sharing änd Stock Bonus Plans: $A$ Discussion, N.Y.U. 14TH INST. ON FED. TAX. 1251, 1278-79 (1956).

"Under a unit-benefit plan, employer contributions equal the market price of annuities calculated to provide upon retirement a stated sum determined by a fixed percentage of each employee's annual compensation for each year of past and current service. See id. at $127 \dot{8}$. 
Employer deductions for contributions to employee trusts were first specifically permitted by the Revenue Act of $1928^{7}$ although they had been permitted as a general business expense prior to that enactment. ${ }^{8}$ As income tax rates became more progressive, pension plans were increasingly used to defer income for employees whose present income was high but whose future income could be expected to decrease, thus reducing their total tax. ${ }^{9} \ln$ an effort to spread the benefits of such plans over the entire employee group, the Revenue Act of 1942 introduced provisions presently found in section 401 (a)(4) which make contributions deductible only if the pension plan is available to employees generally without discrimination in favor of highly compensated personnel.10 Being realistic, however, the draftsmen of the statute apparently did not intend to require exact equality between the benefits received by highly-compensated personnel and other employees but, instead, provided that contributions or benefits might vary as long as the actual operation of the plan did not exclusively or disproportionately favor the upperechelon employees."

A common means of favoring highly-paid employees has been the use of pension plans which provide shorter vesting periods for highlevel employees than for employees as a whole. Such vesting differentials may permit a much greater proportion of highly compensated employees to receive pension benefits since many lowlevel employees will terminate their employment before the delayed vesting of benefits occurs. Prior to 1965, the Revenue Rulings were primarily concerned with discrimination in vesting where all employees were covered by the same plan but the highly compensated groups enjoyed a more favorable vesting provision than the employees as a whole. ${ }^{12}$ However, a 1965 ruling ${ }^{13}$ dealt with a situation in which

\footnotetext{
'Hall v. United States, 7 P-H 1967 FEd. Taxes (19 Am. Fed. Tax R.2d 798) 9 67-423 (D.N.D. Jan. 31, 1967).

' Revenue Act of 1928, ch. 852, § 23(q), 45 Stat. 802 (now INT. REv. CODE OF 1954, § 404).

${ }^{8}$ E.g., Forbes Lithograpb Mfg. Co.v. Wbite, 42 F.2d 287 (D. Mass. 1930); Elgin Nat'l Watch Co., 17 B.T.A. 339 (1929).

${ }^{9}$ See Gordon, Discrintination Problems in the Drafting and in the Operation of Pension and Profit Sharing Plans, N.Y.U. 14TH INST. ON FEd. TAX. I 153 (1956).

${ }^{10}$ Revenue Act of 1942, ch. 619, § 165(a)(4), 56 Stat. 862 (now INT. Rev. Code of 1954, $\S 401(\mathrm{a})(4))$.

"See S. REP. No. 1631, 77th Cong., 2d Sess. 137 (1942).

${ }^{12}$ See, e.g., Rev. Rul. 178, 1965-2 CUm. Bull. 94, 114-15, 120; Rev. Rul. 163, 1957-1 Cum. Bull. 128, 142, 146; Rev. Rul. 33, 1953-1 'Cum. Bull. 267, 280-81.

${ }^{13}$ Rev. Rul. 266, 1965-2 Cum. BuLl. 138-39.
} 
there was a money-purchase plan with immediate vesting for the highly compensated group and a unit-benefit plan with delayed vesting for other employees. Since a unit-benefit plan gave definite stated benefits upon retirement, while the benefits under a moneypurchase plan were dependent upon the amount which the contributions earned through investment prior to retirement, ${ }^{1+4}$ the Commissioner took the position that the benefits would usually be accepted as equal even if some differences existed, provided that it could be shown there was no discrimination in contributions. However, since vesting determined the employees' right to receive the plan's benefits and could be used to exclude all but a favored group from the benefits, the Commissioner determined that any plan with unequal vesting provisions was discriminatory under section 401 (a)(4). ${ }^{15}$

Rejecting the Commissioner's position, the Eighth Circuit concluded in Hall that identical vesting provisions will not necessarily' accomplish the avowed objectives of section $40 \mathrm{f}$ (a)(4), namely, the elimination of the deferral of income for highly-paid employees and prevention of the use of pension plans to provide benefits only for a favored group. ${ }^{16}$ Since vesting was not the sole source of discrimination in favor of upper-echelon employees but was only one of several areas in which discrimination could occur, the court saw no need to single out vesting for special treatment when such treatment was not essential to solving the discrimination problem. ${ }^{17}$ Furthermore, the court was of the opinion that the requirement of identical vesting provisions would constitute an infringement upon the legislative prerogative. It was reasoned that if identical vesting provisions were required, the end result would be increased use of money-purchase plans since most employers would choose to continue giving immediate vesting to the highly-compensated groups. ${ }^{18}$ Although recent presidential studies have approved the general principle of early vesting, they have refused to recommend that Congress establish a minimum-vesting standard. ${ }^{19}$ The court therefore

is See generally Alexander, supra note 4, at 1278-79.

is Rev. Rul. 266, 1965-2 Cum. Bull. 138-39.

16 398 F.2d 383, 389 (8th Cir. 1968).

"Id.

${ }^{18} I d$. at 388.

"Report to the President from the President's Advisory Committee on Labor-Management Policy on the Recommendations by the Cabinet Committee on Corporate Pension 
concluded that since Congress had not acted to establish a mirimumvesting standard, the judiciary should not intervene by forcing business to adopt one through the requirement of identical vesting provisions. Instead, the court restated the rule, first expounded in $1942,2^{20}$ that variations in contributions or benefits are allowable as long as the plan "viewed as a whole" does not discriminate in favor of upper-echelon employees. ${ }^{21}$ Since the district court had heard no evidence with regard to how many employees could be expected to realize the benefits of the plan, the court reversed and remanded to allow both parties to present additional information on the plan's potential operation. ${ }^{22}$

The immediate practical effect of the court's opinion should be to encourage pension plan growth since delayed-employee vesting may reduce the employer's costs and make the plans more attractive to smaller companies. First, with delayed-employee vesting, the forfeited benefits will be used to reduce the employer's contributions to the plan..$^{23}$ Concomitantly, the employee who remains with his job could be the one who benefits by delayed vesting if the company sets plan benefits at a higher level in anticipation of future forfeitures being used to reduce employer contributions. ${ }^{24}$ Second, the Hall opinion provides smaller companies with greater flexibility in tailoring their plans to their own needs and capabilities instead of being told what provisions to use by the local IRS pension trust reviewer. Many local reviewers feel that forfeitures favor the highly compensated group since it most likely consists of those individuals who will stay the longest and receive the most benefits. ${ }^{25}$ Because the highly compensated group is usually larger in proportion to other employees in small firms than in large ones, many reviewers require small companies to provide very quick vesting, which increases employer costs since more employees will receive benefits, regardless of length

Funds and Other Private Retirement and Welfare Programs, primted in PRESIDENT'S Comittee on Corporate Pension funds and Other Private Retrenent and Welfare Prograis, Public Policy and Private Pension Progranis-Report to the President on Private Euployee Retirement Plans, app. D, at 3 (1965) (reprinted in 63 Mich. L. Rev. at 1264 (1965)).

$\because$ See S. Rep. No. 1631, 77th Cong., 2d Sess. 137 (1942).

" Rev. Rul. 178, 1965-2 CuM. BuLl. 94, 119.

22398 F.2d 383, 391 (8th Cir. 1968).

"See Chatterton, Slow Vesting Can Cut Pension C'osts But IRS Opposes lt For Small Firms, 13 J. TAx. 218, 219 (1960).

$\because$ Id.

$\because$ Id. at 221 . 
of service. ${ }^{26}$ With the Hall holding that inequalities in vesting are not discriminatory per se, ${ }^{27}$ a small business can more readily challenge an early-vesting provision demanded by a local reviewer. However, the burden remains on the taxpayer to show that a substantial number of employees will not be exluded from the plan's benefits due to forfeitures caused by the unequal vesting provisions. ${ }^{28}$ By repeating the "plan-as-a-whole" rule, the court has reminded the IRS not to rely on neat formulas but to review each plan on a case-to-case basis, with an awareness that what was discriminatory under one set of circumstances may not be under others. Since the Internal Revenue Service is bound only by a Supreme Court ruling, ${ }^{29}$ the Hall court may have avoided considerable confusion by stating only a general rule, thus leaving the field open for the Commissioner to establish guidelines for a discrimination test rather than imposing a judicial standard which the Commissioner could decide not to follow. But as the court realized, ${ }^{30}$ until such guidelines are established, pension planners, as well as 1 RS agents, will remain uncertain as to when and to what degree unequal vesting provisions will be allowed.

: See id. at 219, 221.

"3 398 F.2d 383, 389-90 (8th Cir. 1968).

"Id. at 390.

¿" See generally 5 P-H 1968 Fed. TAXES $\{141,351$ (b).

${ }^{30} 398$ F.2d at 390. 